\title{
First record of the marine nemertean Evelineus mcintoshii (Langerhans, 1880) (Heteronemertea, Lineidae) in Northeastern Brazil
}

\author{
Rodrigo Vinícius de Almeida Alves ${ }^{1}$, Cecili B. Mendes ${ }^{2}$, Nykon Craveiro ${ }^{1}$ \& José \\ S. Rosa Filho ${ }^{1}$
}

(1) Universidade Federal de Pernambuco, Departamento de Oceanografia, Laboratório de Bentos, Avenida Prof. Moraes Rêgo, Cidade Universitária 50670-901, Recife, Pernambuco, Brazil. E-mail: rodrigovnicius@gmail.com, nykoncraveiro@gmail.com, souto.rosa@ufpe.br.

(2) Universidade de São Paulo, Instituto de Biociências, Laboratório de Diversidade Genômica, Rua do Matão 277, Butantã 05508-090, São Paulo, Brazil. E-mail: cecilimendes@ib.usp.br

Alves R.V.A., Mendes C.B., Craveiro N. \& Rosa Filho J.S. (2019) First record of the marine nemertean Evelineus mcintoshii (Langerhans, 1880) (Heteronemertea, Lineidae) in Northeastern Brazil. Pesquisa e Ensino em Ciências Exatas e da Natureza, 3(2): 147-153. http://dx.doi.org/10.29215/pecen.v3i2.1264

Academic editor: Flavio A. Alves-Jr. Received: 02 October 2019. Accepted: 06 October 2019. Published: 14 October 2019.

Primeiro registro do nemertino marinho Evelineus mcintoshii (Langerhans, 1880) (Heteronemertea, Lineidae) no Nordeste do Brasil

Resumo: O presente trabalho é o primeiro registro do nemertino Evelineus mcintoshii (Langerhans, 1880) no Nordeste do Brasil. O espécime foi coletado em bancos da macroalga Palisada perforata (Bory de SaintVincent) K. W. Nam, 2007 na Praia de Enseada dos Corais (08 $19.07^{\prime}$ S, 34 $56.88^{\prime}$ W). O presente trabalho também representa o primeiro estudo a nível específico sobre Nemertea do Estado de Pernambuco, e a distribuição global atualizada do táxon é provida.

Palavras chave: Novo registro, fital, costa brasileira, praia arenosa.

Abstract: The present work is the first record of the nemertean Evelineus mcintoshii (Langerhans, 1880) in the Northeastern Coast of Brazil. The specimen was collected among beds of the seaweed Palisada perforata (Bory de Saint-Vincent) K. W. Nam, 2007 at Enseada dos Corais beach (08 $19.07^{\prime}$ S, $\left.34^{\circ} 56.88^{\prime} \mathrm{W}\right)$. The present work also represent the first species-level study on Nemertea of Pernambuco State, and the taxon's updated global distribution is provided.

Key words: New record, phytal, Brazilian coast, sandy beach.

\section{Introduction}

Ribbon worms (Phylum Nemertea) are unsegmented bilaterians belonging to a group mainly characterized by the presence of an eversible proboscis located inside a unique body cavity, called rhynchocoel (Thollesson \& Norenburg 2003). They occur in a multitude of habitats in limnic, terrestrial and especially in marine environments, where some species act as important predators in food webs (Thiel \& Kruse 2001; Gonzalez-Cueto et al. 2014). To date, there are more than 1.300 described species worldwide (Norenburg et al. 2019).

Nemertean taxonomy is known to be demanding and requires specific techniques and infrastructure (Sundberg et al. 2016a). In addition, nemerteans can be relatively hard to collect in their habitats. The combination of such factors could underlie on the lack of detailed bibliography (Gonzalez-Cueto et al. 2014) and poor representation of nemerteans in many 
faunistic assessments. In Brazil, one of the most biodiverse countries in the world, the lack of attention on the group is particularly notable. The first study on Brazilian nemerteans was published in 1942 focusing on freshwater habitats (Marcus 1942; Santos \& Norenburg 2011). Later works by Diva Corrêa were responsible for the record and description of about 30 species, most of them in the Southeastern coast (Gibson 1995; Mendes et al. 2016). At present, 50 nemertean species have been recorded in Brazil (Mendes et al. 2016). The work of Mendes et al. (2016) in Ceará State increased the number of species known for the Brazilian Northeastern coast from only two, Baseodiscus delineatus (Delle Chiaje, 1825) and Coenemertes caravela Corrêa, 1966, to nine records (Mendes et al. 2016).

Evelineus mcintoshii (Langerhans, 1880) has a controversial taxonomic history. Its first record in Brazilian waters was from São Paulo State by Corrêa (1954), who described it as a new species, Evelineus tigrillus Corrêa, 1954, belonging to a new genus, Evelineus Corrêa, 1954. Recently, Chernyshev (2016) suggested that Evelineus tigrillus is actually a synonym of Cerebratulus mcintoshii Langerhans, 1880, described from Madeira and later synonymised as Lineus mcintoshii (Herrera-Bachiller et al. 2015). According to Kajihara (2007), the material named as Lineus Mcdntoshii [sic] by Takakura (1898) differs from Langerhans' (1880) original description and should receive a different denomination. In contrast, Chernyshev (2016) argued that L. mcintoshii sensu Takakura possibly is another synonym of $C$. mcintoshii, which corresponds to Langerhans' (1880) description. Also according to Chernyshev (2016), L. mcintoshii is a synonym of Evelineus cf. mcintoshii, found in Vietnamese waters. Therefore, Evelineus mcintoshii is considered the valid name for this species so far (Norenburg et al. 2019).

Based on that, the aim of this work is to report the first occurrence of Evelineus mcintoshii in Northeastern Brazil. As far as we know, this work also represents the first specieslevel study on Nemertea in the State of Pernambuco.

\section{Material and Methods}

The specimen was occasionally collected in beds of the red seaweed Palisada perforata (Bory de Saint-Vincent) K. W. Nam, 2007 on intertidal sandstone rocks (Figure 1) at Enseada dos Corais sandy beach $\left(08^{\circ} 19.07^{\prime}\right.$ S, $34^{\circ} 56.88^{\prime}$ W) in November of 2017.

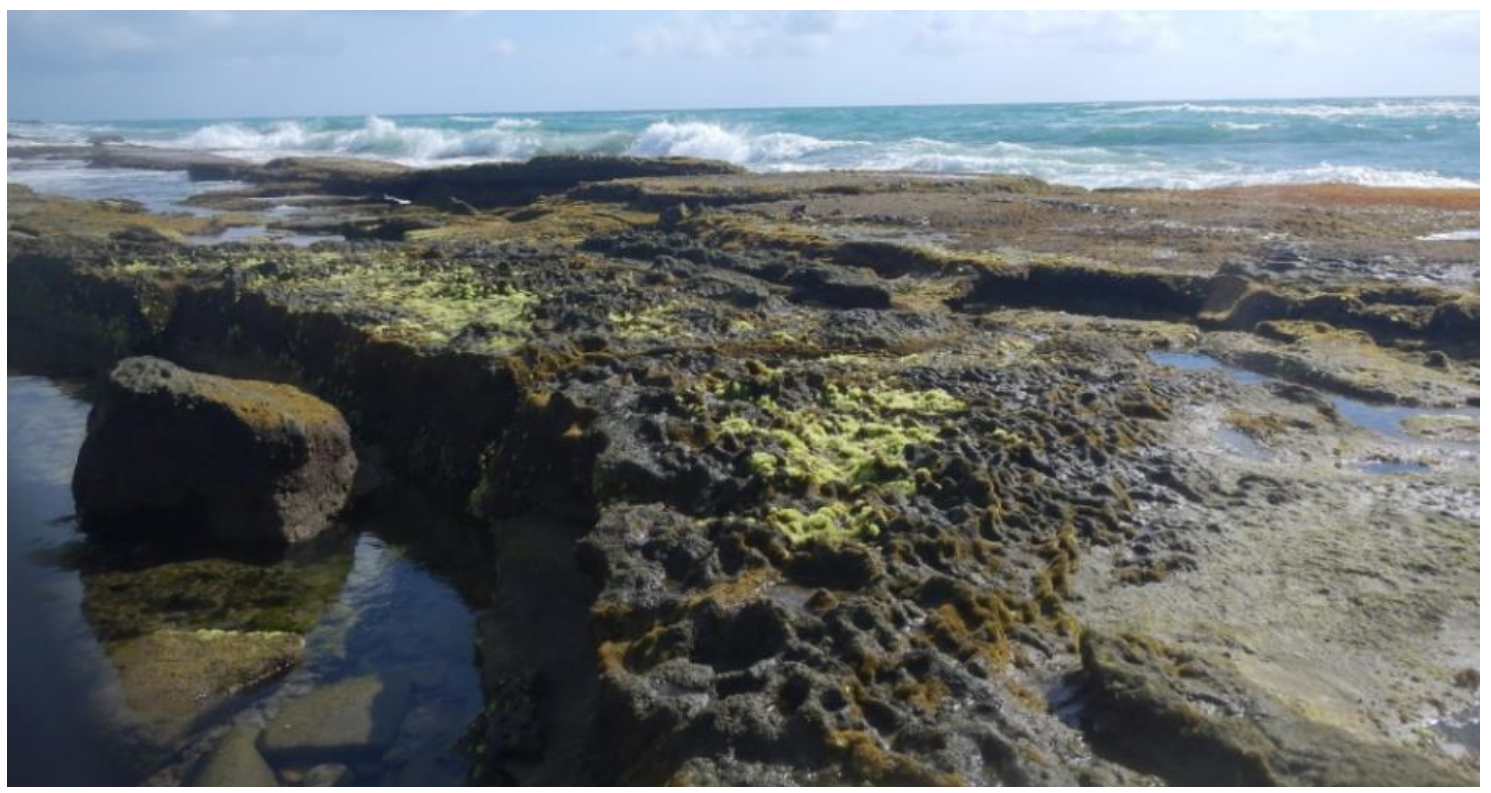

Figure 1. Sandstone rocks of Enseada dos Corais (Pernambuco, Brazil).

The sampling procedure consisted of enclosing algae thalli with plastic bags to prevent the scape of motile fauna. Then, each thallus was physically detached from the substratum and preserved in $4 \%$ saline formalin for a few weeks. The specimen was later sorted from one of the 
collected thalli and conserved in 70\% ethanol. Material was collected under license number 17490-1 issued by Instituto Chico Mendes de Conservação da Biodiversidade (ICMBio). We deposited the voucher specimen in the Marine Invertebrates collection of the Museum of Zoology of the University of São Paulo (MZUSP).

\title{
Results
}

\author{
Class Pilidiophora Thollesson \& Norenburg, 2003 \\ Order Heteronemertea Bürger, 1892 \\ Family Lineidae McIntosh, 1874 \\ Genus Evelineus Corrêa, 1954
}

\section{Evelineus mcintoshii (Langerhans, 1880)}

(Figure 2)

Cerebratulus mcintoshii Langerhans, 1880: 138

Lineus Mcdntoshii [sic]: Takakura (1898: 187, fig. 10).

Lineus mcintoshii (Langerhans, 1880) sensu Takakura (1898); Kajihara (2007: 316).

Evelineus tigrillus Corrêa, 1954: 27-32, figs 19-29.

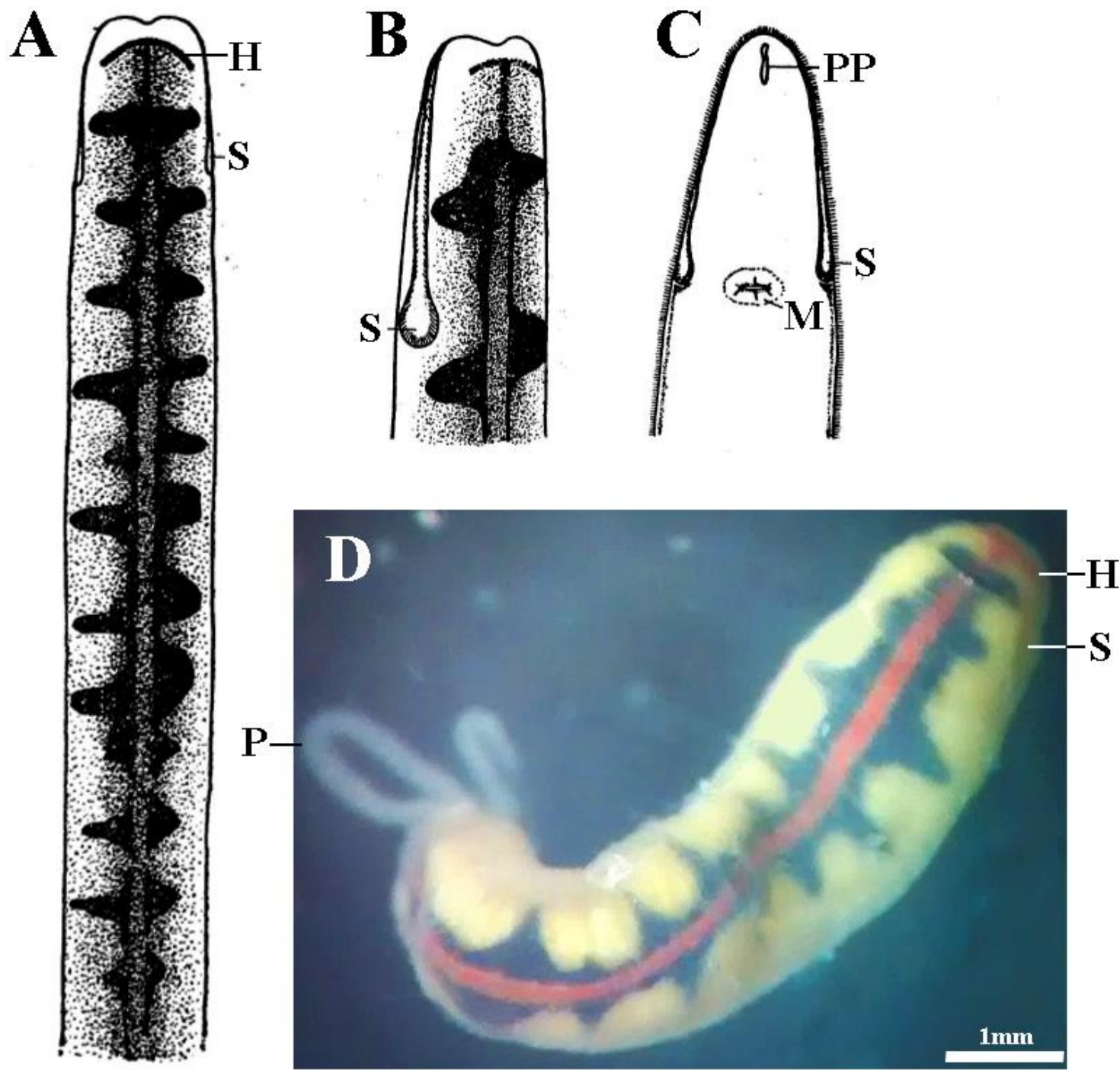

Figure 2. Evelineus mcintoshii (Langerhans, 1880): A. Anterior third in dorsal view; B. Lateral view, showing the cephalic slits; C. Ventral view of anterior region; D. Picture of the collected specimen after fixation in $4 \%$ formalin. There are no photos of living specimen because we fixed the algal sample soon after the collection. A, B and C adapted from Corrêa (1954). H: head pattern, S: cephalic slits, PP: proboscis pore, M: mouth, P: proboscis. 
Type species: Evelineus tigrillus Corrêa, 1954

Material examined: One individual, non-sexed, five millimeters long (after fixation), anterior region only. Brazil, Pernambuco, Cabo de Santo Agostinho, Enseada dos Corais beach, 08 ${ }^{\circ} 19.07^{\prime}$ S, 3456.88' W, 03.XI.2017, collector Rodrigo Alves (MZUSP 609) (Figure 2).

Diagnosis: Body pale, yellowish; dorsal mid-line orange bordered by thin black line, connected with lateral black different sized triangles in both sides. Head tip Orange, bordered connected, with dorsal mid-line. Deep cephalic slits. Long slim body, up to four centimeters long, but never more than two millimeters wide. Anterior third of body wider. No eyes or caudal cirrus present (Modified from Corrêa 1954).

Geographic distribution: North Pacific Ocean (Kajihara 2007; Chernyshev 2016); Indian Ocean (Shynu et al. 2015; Chernyshev 2016); Madeira (Langerhans 1880); North Atlantic (Gibson 2001); Southeastern Brazil (Corrêa 1954) and Northeastern Brazil (present study; Figure 3).

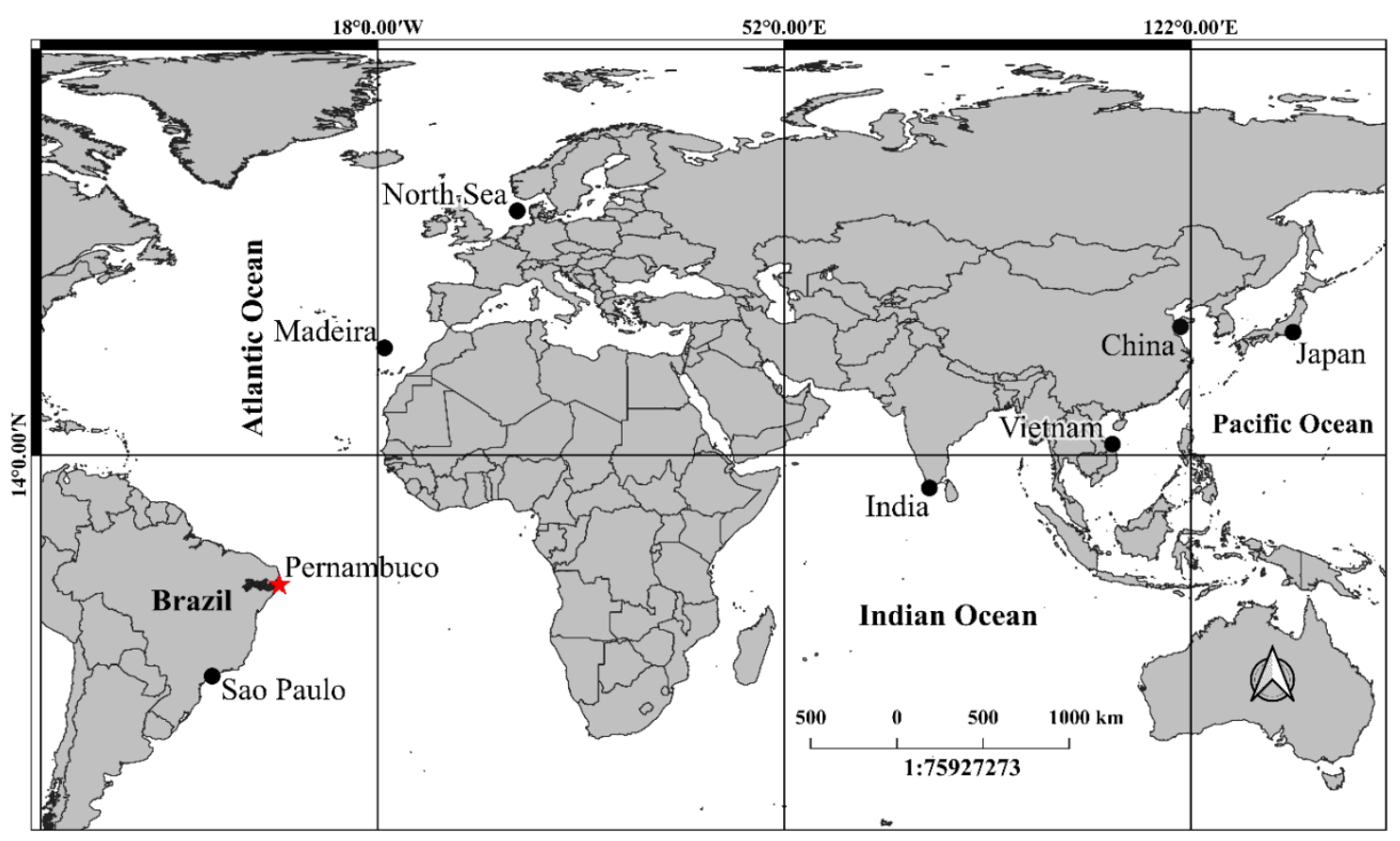

Figure 3. World distribution of Evelineus mcintoshii (Langerhans, 1880) based on literature (Corrêa 1954; Kajihara 2007; Shynu et al. 2015; Chernyshev 2016). The red star represents the new record for the species.

Remarks: Like our record, Evelineus tigrillus Corrêa, 1954 possesses a curve line, resembling an arch, on the head and the dorsal mid-line is bordered by a black line in the first third of the body. Both Brazilian specimens differ from Evelineus cf. mcintoshii found in Vietnam in the color pattern of the dorsal surface. The Vietnamese one has dorsal black lines, whereas the Brazilian specimens have black triangles. Futhermore, the Brazilian specimens also differ from the one found in Madeira, which has a semicircle on the cephalic region and no black border along the dorsal mid-line.

\section{Discussion}

All specimens of Evelineus mcintoshii (Langerhans, 1880) so far were found on hard substrata at shallow, coastal areas (Corrêa 1954; Gibson 1995; Shynu et al. 2015; Chernyshev 2016). Almost all records indicate some sort of habitat association with macroalgae, or dead corals as observed by Chernyshev (2016). There is minimal to no information on the biology of the species. Corrêa (1954) reported more than 30 individuals after samplings in different 
localities along the coast of São Paulo. In the present study, we did not apply the common techniques for sampling nemerteans in the field. This may explain the low abundance observed for the species in the sampling location (only one individual found). However, in 2019, one of the authors (CBM) collected in the same localities visited by Corrêa and was not able to find more than two specimens, despite extensive sampling and appropriate technique. Corrêa (1954) also noticed the presence of dense amounts of polychaete setae inside the intestine of one specimen, which can give some information on the feeding preferences of this animal.

The family Lineidae is part of a monophyletic group (Pilidiophora) characterized by a unique, long-lived larva called pilidium (Maslakova 2010). Although data on nemertean dispersal are scarce, species with this kind of larva, e.g. Parborlasia corrugatus (McIntosh, 1876), can probably cross relatively long distances (Thornhill et al. 2008). However, it is also known that oceanic currents and land masses can act as important physical barriers to dispersal in the marine environment, which can decrease the gene flow between geographically distinct populations and result in allopatric speciation (Thornhill et al. 2008). We doubt that the two known populations of Evelineus mcintoshii in the Brazilian Coast (from São Paulo and Pernambuco, respectively) are different species due to several similarities of their external features and habitats. However, genetic studies are necessary to evaluate the genetic connectivity between the "southern" and "northern" populations in Brazil. Considering the lack of studies on the diversity of Brazilian ribbon worms, we would not be surprised by new findings of this same species in different sites along the Brazilian coast, forming sort of stepping stones connecting in some degree both populations through gene flow.

New findings as observed in this paper also raise the hypothesis of possible introduction driven by anthropogenic forces. That hypothesis is supported by the sampling site's location between two important commercial shipping ports of Pernambuco: Suape and Recife harbors. The Harbor of Recife receives a considerable amount of ships and boats from different parts of Brazil and other countries, and unidentified nemerteans have already been found associated with seaweeds as fouling organisms attached to the hulls of different vessel types operating in this area (Farrapeira et al. 2007). Considering the relatively long lifespan of the typical pilidium larva, we also regard the possibility of transport and accidental introduction through discharge of ballast water from ship's tanks near the coast.

According to Corrêa (1954), the species possesses "the most beautiful set of colors and drawings among the known Nemertini species of the Brazilian littoral” (authors' translation). Herein, we pointed out differences on the coloration pattern between the specimens collected in Brazil so far and the specimens from Vietnam and Madeira, respectively. It is known that external features are very important in Nemertean taxonomy and can be used to discriminate species, especially if combined with DNA techniques, rather than internal characters (Sundberg et al. 2016b). Therefore, we suggest further investigation using molecular tools to unravel whether such color differences are in fact only intra-specific variations or represent different species. Such information could be of major importance to evaluate the taxon's conservation status. Finally, to clarify if all populations found worldwide so far are in fact the same species, we suggest recollections in the locations cited here (if not done yet), since many of the specimens are either missing, like the original materials examined by Takakura (Dr. Kajihara's personal communication) and Corrêa, or not correctly preserved for molecular analysis (like our specimen). Due to the current lack of molecular data, we accepted Evelineus mcintoshii as the valid name of our specimen, in agreement with recent views (Chernyshev 2016). With the present study, we record the nemertean Evelineus mcintoshii for the first time in the Northeastern Coast of Brazil.

\section{Acknowledgements}

The present work was supported by CNPq/PIBIC grant 162347/2018-9 to RVAA. The authors thank the two anonymous reviewers for their fruitful comments and Dr. Leandro M. Vieira (UFPE) for early suggestions on the manuscript. 


\section{References}

Chernyshev A. (2016) Nemerteans of the coastal waters of Vietnam (p. 279-314). In: Adrianov A.V. \& Lutaenko K.A. (Eds). Biodiversity of the Western Part of the South China Sea. Vladivostok: Dalnauka. 502 p.

Corrêa D.D. (1954) Nemertinos do Litoral Brasileiro. Boletim da Faculdade de Filosofia Ciências e Letras São Paulo (Zoologia), 19: 1-90. https://doi.org/10.11606/issn.25263382.bffclzoologia.1954.120084

Corrêa D.D. (1966) A new hermaphroditic nemertean. Anais da Academia Brasileira de Ciências, 38(2): 365-369.

Delle Chiaje S. (1825) Memorie sulla storia e notomia degli animali senza vertebre del regno di Napoli (Vol II). Napoli: Stamperia della societa tipografica. 444 p.

Farrapeira C.M., Melo A.V., Barbosa D.F. \& Silva K.M. (2007) Ship hull fouling in the Port of Recife, Pernambuco. Brazilian Journal of Oceanography, 55: 207-221. http://dx.doi.org/10.1590/S1679-87592007000300005

Gibson R. (1995) Nemertean genera and species of the world: an annotated checklist of original names and description citations, synonyms, current taxonomic status, habitats and recorded zoogeographic distribution. Journal of Natural History, 29: 271-562. https://doi.org/10.1080/00222939500770161

Gibson R. (2001) Nemertini (p. 152-156). In: Costello M.J., Emblow C. \& White R.J. (Eds). European register of marine species: a checklist of the marine species in Europe and a bibliography of guides to their identification. Paris: Publications Scientifiques du M. N. H. N. $463 \mathrm{p}$.

Gonzalez-Cueto J., Quiroga S. \& Norenburg J.L. (2014) A shore-based preliminary survey of marine ribbon worms (Nemertea) from the Caribbean coast of Colombia. ZooKeys, 108(439): 83-108. https://doi.org/10.3897/zookeys.439.5965

Herrera-Bachiller A., Fernández-Álvarez F.A. \& Junoy J. (2015) A Taxonomic Catalogue of the Nemerteans (Phylum Nemertea) of Spain and Portugal. Zoological Science, 32 (6): 507-522. https://doi.org/10.2108/zs140242

Kajihara H. (2007) A Taxonomic Catalogue of Japanese Nemerteans (Phylum Nemertea). Zoological Science, 24(4): 287-326. https://doi.org/10.2108/zsj.24.287

Langerhans P. (1880) Die Wurmfauna von Madeira. III. Zeitschrift für Wissenschaftliche Zoologie, 34: 87-146.

Marcus E. (1942) Sôbre um nemertino d'água doce do Brasil. Anais da Academia Brasileira de Ciências, 14: 371-383.

Maslakova S. (2010) The Invention of the Pilidium Larva in an Otherwise Perfectly Good Spiralian Phylum Nemertea. Integrative and Comparative Biology, 50: 734-743. https://doi.org/10.1093/icb/icq096

Mendes C.B., Matthews-Cascon H. \& Norenburg J.L. (2016) New records of ribbon worms (Nemertea) from Ceará, Northeast Brazil. Zootaxa, 4061(2): 146-156. https://doi.org/10.11646/zootaxa.4061.2.4

Nam K.W. (2007) Validation of the generic name Palisada (Rhodomelaceae, Rhodophyta). Algae, 22(2): 53-55. https://doi.org/10.4490/ALGAE.2007.22.2.053

Norenburg J.L., Gibson R., Herrera Bachiller A. \& Strand M. (2019) World Nemertea Database. Available at: http://www.marinespecies.org/nemertea/ (Accessed in 25/09/2019).

Santos C. \& Norenburg J.L. (2011) Nemertea (p. 85-99). In: Amaral A.C. \& Nalli S.A. (Eds). Biodiversidade e ecossistemas bentônicos marinhos do litoral norte de São Paulo - Sudeste do Brasil. Campinas: Unicamp/IB. 573 p.

Shynu S.P., Shibu S. \& Jayaprakas V. (2015) First record of nemertean Lineus mcintoshii (Nemertea: Anopla: Heteronemertea) from the Indian coast. Marine Biodiversity Records, 8: 10-11. https://doi.org/10.1017/S1755267215000020 
Sundberg P., Kvist S. \& Strand M. (2016a) Evaluating the utility of single-locus DNA barcoding for the identification of ribbon worms (phylum Nemertea). PLOS ONE, 11(5): 1-17. https://doi.org/10.1371/journal.pone.0155541

Sundberg P., Andrade S.C., Bartolomaeus T., Beckers P., Döhren J.V., Kramer D., Gibson R., Giribet G., Herrera-Bachiller A., Junoy J., Kajihara H., Kvist S., Kanneby T., Sun S-C., Thiel M., Turbeville J. \& Strand M. (2016b) The future of nemertean taxonomy (phylum Nemertea) a proposal. Zoologica Scripta, 45(6): 1-4. https://doi.org/10.1111/zsc.12182

Takakura U. (1898) Misaki-kinbosan-himomushirui-(Nemertine)-nobunrui [A classification of the nemerteans of the Misaki region]. Zoological Magazine, 10: 184-187.

Thiel M. \& Kruse I. (2001) Status of the Nemertea as predators in marine ecosystems. Hydrobiologia, 456: 21-32. https://doi.org/10.1023/A:101300581414

Thollesson M. \& Norenburg J.L. (2003) Ribbon worm relationships: A phylogeny of the phylum nemertea. Proceedings of the Royal Society B: Biological Sciences, 270(1513): 407-415. https://doi.org/10.1098/rspb.2002.2254

Thornhill D.J., Mahon A.R., Norenburg J.L. \& Halanych K.M. (2008) Open-ocean barriers to dispersal: a test case with the Antarctic Polar Front and the ribbon worm Parborlasia corrugatus (Nemertea : Lineidae). Molecular Ecology, 17: 5104-5117.

https://doi.org/10.1111/j.1365-294X.2008.03970 